\title{
SETTING UP AN ADULT ESL PROGRAM IN THE FIJI ISLANDS
}

\section{Myra Thorkelson}

There was Vimla, a twenty-three year old Indo-Fijian, who wanted to be exposed to an 'American' accent; Rupeni, forty-three, came because his employer said he had to; Serita, twenty-seven, was looking for an interest and social occasion acceptable to her strict Moslem family; Louisa, Fijian, the fifty-year-old wife of a United Nations' employee recently appointed to Pakistan, registered so she could practice English conversation and be more comfortable at her husband's side; Samuela, a night security guard with only three years of formal schooling, never missed a class despite his mates teasing him about attending Kindergarten.

These were some of the students who attended an Adult English as a Second Language class at the YMCA in Suva, capital of the Fiji Islands. Fiji's population is mainly comprised of two large groups. Fifty-one percent are Indo-Fijians and forty-four percent are indigenous Fijians. The Indo-Fijians were brought to Fiji in the late 1800's (by the British) to work on the sugar plantations. Many remained and now inhabit Fijis three hundred and thirty-two islands in greater numbers than the nativeborn Fijians. These Indo-Fijians speak a dialect of Hindi. The Fijians speak a dialect of Fijian. The common language is English.

All educational and economic, and many social transactions, are carried out in English. In Suva, two of the four daily newspapers are published in English. On the two local stations, fifty percent of all radio broadcasting is also in English. Even the national anthem of Fiji is sung in English.

It is therefore almost mandatory for the inhabitants of Fiji to understand and speak English in order to do their banking, shopping, and cross-cultural socializing. Thus, the students who responded to the YMCA's advertisement were wanting to improve on a skill both necessary to their daily lives and a pre-requisite of most employment in Fiji.

A multi-level class with such a variety of needs was a real challenge to my ESL background of teaching adult immigrants in Canada. I therefore began by having the students design their own curriculum, thus ensuring that the one and a half hour classes held twice a week would be both practical and pertinent.

The first class was an introductory session in which the twelve students and the teacher got to know each other. I also gave the students instructions on how to use a pie-graph. The students' homework was to divide a circle according to what areas of the English language were important to 
them and to list in order of importance what they wished to study in the ESL classes.

The students broke up into small groups in the second class and came up with a completed group list of what English skills they wished to study. The four groups reported back and four skill areas were chosen from the group lists. These skills would be the foundation for the curriculum.

My job as facilitator of this course emerged. I would have to design a course of ESL lessons which would cover the students' requirements as outlined in their group needs. The activities would thus be oriented to problem areas generated by the participants themselves.

The following skill areas predominated when the four groups returned with their completed pie graphs.

\section{Reporting Skills}

The students felt they wanted to be able to tell a story in a logical way so that the people listening would be interested, know what had happened, and have all the important information.

\section{Emotional English}

Participants felt that they reverted to their mother tongue under stressful conditions or during times of excitement. They wanted to express their "gut" feelings better in English.

\section{Listening Skills}

The participants of all the groups felt that they missed a lot listening to English conversation, especially in groups of people when more than one person is talking.

\section{Vocabulary Building}

All the students felt that increasing their vocabulary was one reason for attending the ESL class.

The pie-graph was thus a needs assessment of the twelve participants. This simple type of assessment could easily augment curriculum planning in Canadian adult education and help planners to get a feel for the needs of their students and make use of this information to modify their teaching. Adult students are only too happy to write down why they are attending a class and, if the curriculum doesn't meet their needs, will soon drop out.

A few techniques that were used in the following weeks to teach the four skill areas follow:

\section{Reporting Skills}

The Fiji Times is widely circulated and read in Fiji. I cut out and photocopied an article from the daily paper. After silent reading, the class discussed the article and answered five "WH" questions: "What hap- 
pened?"; "Where did it happen?"; "Why did it happen?"; "When did it happen?"; and "Who did it happen to?" on the chalkboard. When all this information had been collected and the group had agreed on the answers, I orally reported the story back to the students in my own words and included the five answers from the chalkboard. The listeners had to verify that my report was correct in its details.

This reading of a newspaper article, answering of questions, oral feedback, and group agreement was modelled several times. Then it was the students' turns to play all the parts. One student became recorder at the board. Another student read out the article and the recorder, with help from the group, tried to answer the "WH" questions on the board. When all the questions had been answered, the recorder attempted to retell the story in his/her own words. The reader and the rest of the class interrupted to correct any misinformation.

This was a very difficult exercise for the class. Though they all read the English newspaper, it became obvious that they understood very little of what they read. Most of them had trouble finding, and verbally expressing, the main idea of a newspaper article. In subsequent classes, each student brought in newspaper articles for the activity. Even though they chose their own article, they often mispronounced words which resulted in errors of understanding that were recorded on the chalkboard and not corrected by the rest of the students. At first, when the story was retold, it was often a poorly sequenced account, bearing no resemblance to the source.

It quickly became clear to both teacher and class that more work was needed on finding information, sequencing of events, and pronunciation. We spent time over the next four weeks on these areas. We also did comprehension, skimming, and precis exercises to help the students understand and orally summarize what they were reading.

It was not until the second five-week session that the students could start to answer the who/what/where/when/why questions accurately, and do this activity more successfully.

At the end of each class, students were asked to record their observations about the lesson in a diary. I also wrote down observations so I could modify or improve my future lesson plans.

In her diary, Nun wrote: "In this lesson, I learned how to read a long story and try to tell the same story in a short form, telling the main points and making a person understand about the story."

In my diary, I observed: "It is a revelation to me that most of my students have trouble reading and understanding the daily newspaper though they have admitted that they love to buy it and read it every day. Motivation is high in this activity as the students can see it will lessen their frustration with a daily event." 


\section{Emotional English}

Emotional English is a term I used to describe the language used in situations of stress or elation after it became apparent that the students were shy about expressing themselves in English. I used role play as the teaching technique for improving this skill.

Each student received an identical sheet detailing a situation relevant to their lives. After preparation time for discussion and character familiarization, each student assumed one of the roles.

At first, the students were very inhibited, reading and reciting only what was written on the prepared page. Gradually, they began to prepare at home and some even appeared wearing costumes. We used situations from the "Letters-to-the-Editor", moral and social issues, and relevant lifestyle issues, such as popular music, inflation, in-law problems, racial prejudices, etc.

The best way to show the growth of this skill is to quote from the students' and teacher's diaries: "Even some of us who spoke less started to talk a lot because when we have arguments, one wants to be ahead."

"Now I'm not afraid to speak in public or in the meeting."

"It helped me speak and make someone else understand about my point of view."

"Even some of us were shy at first. Now everyone gets a turn to talk and we have a lot of arguments, laughing and a lot of fun."

Teacher observation: "Lise brought tears to our eyes today as she played the priest talking about euthanasia. She actually read from her paper with downcast eyes just three weeks ago. Today, she almost hit Rupeni and not one word of Hindi or Fijian."

\section{Listening Skills}

Cloze exercises were used to develop listening skills. I pre-recorded passages from articles I thought would interest the students. Each student received two copies of the typed article with every seventh word missing. On the first sheet, the students tried to fill in the blanks by predicting. This helped to familiarize them with the subject and gave them time to think about the completion of the passage.

The tape was then played several times and students listened and attempted to complete the second sheet with the words they heard.

The passages used in these Cloze exercises were chosen to have maximum interest for the students. For instance, I recorded a conversation at a cocktail party. The conversation was then typed up as a cloze passage and students had to listen to seven or eight voices with varying accents and fill in their sheet. One student brought in a hymn he was having trouble learning. Radio broadcasts, stories and telephone conversations made up into interesting cloze exercises and were relevant to the participants' lives. 
Jung Kok, wife of the Korean Charge d'Affairs in Fiji, observed in her diary during the second five-week session: "Cloze passage has helped me at my diplomatic functions. It was very difficult to understand when many people speak English at once. I used to just smile but now I can say something. I now understand every fifth word. I hope I will later understand every word."

Teacher observation: "The class is multi-level, multi-cultural, and has multi-interests. I am having trouble finding cloze exercises that appeal to everyone. However, the students are making suggestions and even recording different conversations."

\section{Vocabulary Building}

Expanding the vocabulary was built into all lessons as unfamiliar words occurred in cloze passages, role play situations, and newspaper articles. Whenever a new word cropped up, the meaning of the word was discussed. It was used in sentences and explained in context. Many of the students listed these new words and their definitions in the back of a notebook.

In addition, we did a few exercises aimed specifically at enlarging the participants' working vocabulary. For instance, each student brought one new word he had encountered in his work or reading to each lesson. That word was listed for the class and its meaning placed beside it. Each student tried to use the word in a sentence. Often the students had difficulty understanding how to use the word. Was it a noun, an adjective, or a verb?

We spent some time on learning the parts of speech, and supplementary sheets - such as Figure 1 - were helpful. The words in Figure 1 were ones that the students had brought to class.

\section{Figure 1}

Give the correct form of the words in brackets, as is done in the example.

EXAMPLE: There is a possibility that you will be on the rugby team.

(possible)

1. There was a __ of mangoes because the weather had been too dry. (scarce)

2. Louisa gave an interesting about the funeral customs of her people.

(explain)

3. The new school building was opened by an important

(parliament)

4. The boys gave a __ cheer at the end of the cricket match; they had won.

(triumph)

5. "The ___ of a unilingual Fiji should be obvious", Nacanieli said in his speech.

(absurd) 
We also played "Fictionary" (Thorkelson, M. 1984) to help learn new vocabulary. Again, the best evaluation of what the students learned came from their own observations:

Vimla wrote: "She taught us some very hard words which we could not pronounce properly, but the way she taught, now these words are very easy and we can use it always while speaking."

Teacher observation: "The words learned during the often hysterical laughter of Fictionary seemed to stay with the students and they were heard to use them again and again. Ironically, I am surprised to find that Fictionary has really increased my vocabulary and my family often say, 'What does that mean?', when I use the unfamiliar word so comfortably."

The ESL classes ran for five weeks. We then had a one-week break and began again for a second five weeks. All the students re-registered for a second five weeks and the skill areas of reporting, emotional English, listening, and vocabulary were continued for the second, third and fourth five-week sessions.

The students' original goal - i.e., "to become a better verbal reporter" - was broken down into smaller skills such as precis, skimming, finding the main idea, speaking more clearly, asking questions to draw out information, and reading comprehension, which all led to better reporting. Each skill, thus broken down, took much longer than the five weeks to teach.

I evaluated this voluntary, informal, adult education program on a qualitative, rather than a quantitative, scale. As sole teacher, curriculum designer, administrator, and facilitator, I felt I was too biased to resist "teaching to a test". Besides, my students were not coming to the class to get a mark to show they were mastering English. They came so they could function more efficiently, socially and career-wise, in an English-speaking society. No one would be asking for grades to prove this.

Therefore, I resorted to qualitative evaluation of my own teaching and of the students' learning. I principally relied on teacher and student observations through the use of journals. The journals were a part of each lesson. A few minutes were set aside at the end of the lesson and students were encouraged to write down observations on the lesson. I have used quotations from these written accounts throughout this paper.

My observations did help me improve planning of future lessons. I could spot lessons that were inefficient in this cultural setting and try an alternative method. The fact that one hundred percent of the students re-enrolled for three consecutive sessions might have been an evaluation itself.

In an informal interview conducted four months after the program, I found that of the original twelve students - two have been promoted; one shy Moslem housewife has gotten a job as a hairdresser; Sameula is now 
working the day shift, dealing with the public in English; Louisa, back from Pakistan, reports feeling more comfortable at diplomatic functions; and the rest reported improved self-confidence, even though their positions have not changed.

I think there is a definite place for adult ESL classes in Fiji and hope that the non-formal section of the Fiji Department of Education will consider funding such classes in the future. To my knowledge, this was the first time a voluntary ESL class had been offered in Suva.

\section{REFERENCES}

Thorkelson, M. (1984). Fictionary. TESL Canada Journal 2 (1).

\section{THE AUTHOR}

Myra Thorkelson has a Bachelor of Science and Bachelor of Education from the University of Manitoba. She is currently writing her Masters of Adult Education thesis for St. Francis Xavier University. She was a CUSO employee in Tanzania from 1966 - 1970 and taught EFL. She taught ESL classes at Holland College, Charlottetown, from 1980 - 1984. She was the recipient of the Ruth Crymes TESOL Fellowship in 1983, and was also P.E.I.'s TESL Canada representative from 1982-84. In 1984, she and her family moved to Suva, Fiji for two years and Myra taught Literacy and Intermediate ESL at the YMCA in Suva. She is presently employed as an ESL and Remedial teacher with the Unit Four School Board of Prince Edward Island. Mrs. Thorkelson is married and has three children. 